\title{
Polymer Coating Effects: Study of Material Properties and Architectural Application Characteristics of Aluminum Template
}

\author{
Fei Shuo Hung
}

check for updates

Citation: Hung, F.S. Polymer Coating Effects: Study of Material Properties and Architectural Application Characteristics of Aluminum Template. Coatings 2021, 11, 240. https://doi.org/10.3390/ coatings 11020240

Academic Editor: Csaba Balázsi

Received: 15 January 2021

Accepted: 15 February 2021

Published: 17 February 2021

Publisher's Note: MDPI stays neutral with regard to jurisdictional claims in published maps and institutional affiliations.

Copyright: (C) 2021 by the author. Licensee MDPI, Basel, Switzerland. This article is an open access article distributed under the terms and conditions of the Creative Commons Attribution (CC BY) license (https:/ / creativecommons.org/licenses/by/ $4.0 /)$.
Department of Leisure, Recreation and Tourism Management, Southern Taiwan University of Science and Technology, No. 1, Nantai Street, Yongkang District, Tainan 71005, Taiwan; fshung@stust.edu.tw

\begin{abstract}
In construction process, the formwork must be in contact with concrete to help the concrete solidify and fix the shape. Coating the formwork with a polymer can prolong its service life by reducing the amount of concrete sticking to the mold. Herein, an aluminum template substrate was coated with polyvinylidene difluoride (PVDF) or polyurethane (PU). Aluminum template material analysis was conducted, polymer film thickness was measured, and weather, moisture, pollution, salt spray, abrasion, impact, and acid and alkali resistance tests were conducted, as were tensile, bending, adhesion, hardness, and salt water resistance tests. Cement adhesion resistance was repeatedly tested. The experimental results indicated that the PVDF-coated template was superior. The novel PVDF Aluminum template exhibited high corrosion resistance and can be used in building materials, for example, in ceilings, partition walls, curtain walls, roof panels, and roof trusses. For reference, it can also be applied to ship structures and seaside and wind power generation projects.
\end{abstract}

Keywords: aluminum alloy; coating; aluminum template; polyvinylidene fluoride; polyurethane

\section{Introduction}

The design and application of aluminum alloy formwork represents a new generation of building formwork, especially for improving the construction efficiency and reducing the environmental impact [1-3]. The key points of the application and construction of green building materials include green construction management, environmental protection, and the saving of materials, water, energy, and land. In construction, aluminum formwork has the advantages of high strength and resistance to acids and alkalis, cold, heat, moisture, and deformation. It is suitable for operations in environments at various temperatures and is especially suitable for rapid building construction. Furthermore, aluminum-type material has strong bearing capacity and is light. It enables zero discharge of construction waste to be achieved during the construction process, reducing both the pressure of waste on the environment and the consumption of materials [4-7].

Aluminum-magnesium series alloys belong to the 5000 series of Aluminum alloys, which are non-heat-treated aluminum alloys that have a process strengthening effect. Therefore, large-scale 5000 series Aluminum alloys have no heat treatment problems. Therefore, the 5000 series $\mathrm{Al}$ alloys are used for constructing trains or ships. Furthermore, $\mathrm{Al}-\mathrm{Mg}$ alloys exhibit excellent corrosion resistance but poor wear resistance. Therefore, in this study, the elements $\mathrm{Cu}$ and $\mathrm{Cr}$ were added to a 5000 series aluminum alloy. The 5089 Aluminum alloy material was then prepared and its surface coated with polymer, and its relevant application characteristics were reviewed.

Polyvinylidene fluoride (PVDF) is an environmentally friendly and medical material [8-10]. It has the characteristics of both fluororesin and general resin in addition to favorable chemical resistance, high temperature resistance, electrical insulation properties, and oxidation, weather, and radiation resistance. It is also piezoelectric, dielectric, and 
thermoelectric, with wear and impact resistance. Furthermore, it has high fade and ultraviolet resistance in extremely harsh environments and can be used outdoors for long periods [11-17].

Polyurethane (PU) is easy to process and has favorable physical and chemical properties, high abrasion resistance, high flexibility, high tensile strength, great elongation, good chemical resistance, and excellent elasticity. Additionally, it has low volatile organic compound content, causes low or no environmental pollution, and is convenient in construction. In recent years, PU has been widely used in outdoor sports and leisure equipment coatings [18-22].

In view of this, this study coated the surface of a 5089 Aluminum alloy template with PVDF and PU materials. The aluminum alloy is fully functional and environmentally friendly, but also, more crucially, it can overcome the construction disadvantages of poor corrosion resistance and low wear resistance. The present results are of great importance to the application of aluminum alloys in coastal resorts, airports, highways, and general construction and can provide references for ship and wind power projects. In this innovative study, the polymer coating on the 5089 lightweight Aluminum template was used to study the applicability of architectural technology $[23,24]$.

\section{Experimental Procedure}

First, the surface of the 5089 Aluminum template was boiled at $70-80{ }^{\circ} \mathrm{C}$ for 30 $40 \mathrm{~min}$ to remove grease and other impurities. The template was then left to dry at room temperature. The size of the aluminum template was $15 \mathrm{~cm} \times 5 \mathrm{~cm} \times 1 \mathrm{~mm}$. PVDF and PU coatings were applied to the template. The template coating layer was divided into a bottom layer of thickness approximately $20 \mu \mathrm{m}$ and outer layer of thickness $30 \mu \mathrm{m}$; between each coating, the template was left to set for $1 \mathrm{~h}$ at room temperature. In the experiment, in addition to analyzing the thickness of the front and back coating films of PVDF and PU substrates, the hardness was tested, weather, moisture, pollution, salt spray, abrasion, impact, tensile, bending, adhesion, salt water, and acid and alkali resistance tests were conducted, and other material properties were reviewed; each test was conducted in accordance with ASTM specifications. Furthermore, in accordance with the Chinese National 61 gold-grade standard for environmentally friendly cement, an appropriate amount of cement was applied to the aluminum formwork after proportioning and allowed to stand at room temperature for $72 \mathrm{~h}$. PVDF and PU aluminum formwork concrete adhesion tests were performed for obtaining three-point probe results $(1,5$, and 10 times). In addition to investigating the organization, each test involved computer image analysis of the coating characteristics. Test pieces were also processed for tensile and particle erosion abrasion tests. The tensile test was performed using a universal testing machine with a tensile rate of $1 \mathrm{~mm} / \mathrm{min}$ and initial tensile strain rate of $8.33 \times 10^{-4} \mathrm{~S}^{-1}$. The particle erosion test apparatus is depicted in Figure 1. The selected erosion particles were irregularly shaped $295-\mu \mathrm{m}$ silica sand. In all, $500 \mathrm{~g}$ of erosion particles was used; the inlet pressure value was $3 \mathrm{~kg} / \mathrm{cm}^{2}(0.29 \mathrm{MPa})$; the erosion angles were $15^{\circ}, 30^{\circ}, 45^{\circ}, 60^{\circ}$, $75^{\circ}$, and $90^{\circ}$; and the material weight loss $(\delta \mathrm{W})$ after erosion and single shot were measured. The total weight ratio $(\mathrm{W})$ of erosion particles is the erosion wear rate $(\mathrm{ER} \%=\delta \mathrm{W} / \mathrm{W})$. In addition, the deterioration of the material after the salt spray test was analyzed. Therefore, the salt spray (625-h and 1250-h) test pieces underwent a tensile test to compare the chlorination effect and obtain corrosion resistance data. The relevant experimental results were the average of three to five measurements. 


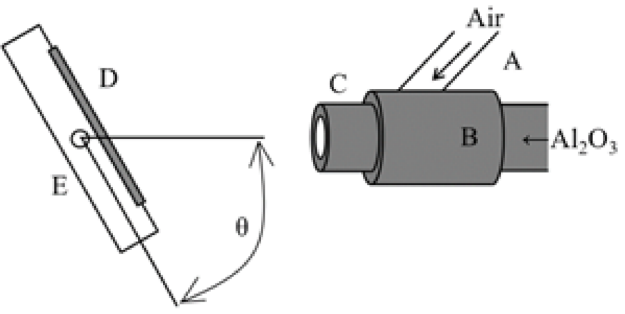

Figure 1. Apparatus for the particle erosion test (A: compressed air flow; B: erosion particle supplier; C: erodent nozzle; D: specimen; E: specimen holder; $\theta$ : impact angle).

\section{Results and Discussion}

As Figure 2 indicates, the average grain size of the 5089 template was approximately $32 \mu \mathrm{m}$, and it was evenly distributed in the base. The base hardness was HRB 62, and the alloy base exhibited an equiaxed structure. The fine dark particles are silicon particles, and considerably magnesium. Solid solution was evident in the aluminum matrix, and the organization was homogeneous, with both these factors having a strong effect on the strength of the base. X-ray diffraction analysis revealed that the entire 5089 template was almost aluminum base; a small amount of $\mathrm{Al}_{6} \mathrm{Mn}$ phase, which belonged to the solid solution strengthening system, was present (Figure 3; Table 1).

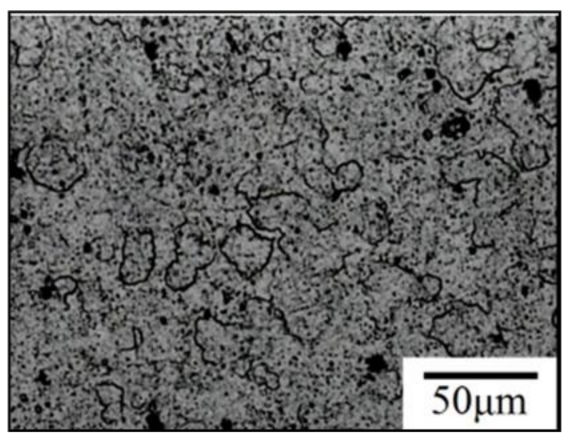

Figure 2. Surface characteristics of the 5089 alloy.

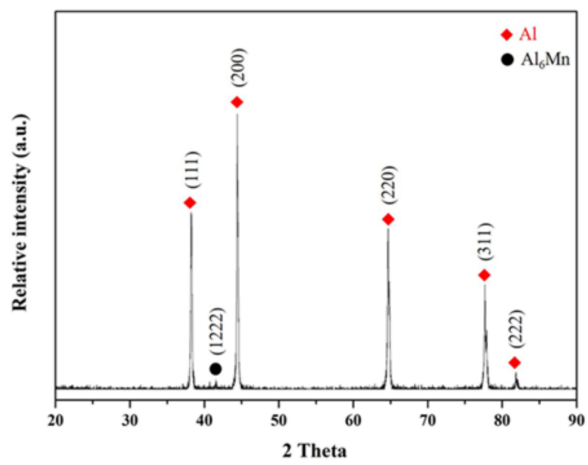

Figure 3. X-ray diffraction (XRD) results of the 5089 alloy

Table 1. Chemical composition of the 5089 Aluminum alloy (wt.\%).

\begin{tabular}{ccccccc}
\hline Al & $\mathbf{M g}$ & $\mathbf{S i}$ & $\mathbf{M n}$ & $\mathbf{C r}$ & $\mathbf{C u}$ & $\mathbf{F e}$ \\
\hline Bal. & 4.22 & 0.48 & 0.72 & 0.16 & 1.28 & 0.25 \\
\hline
\end{tabular}

The subsurface of the PVDF aluminum alloy template was analyzed using an image analyzer, Figure 4a,b. The coating thickness of the PVDF front surface had an inner layer of $22 \mu \mathrm{m}$ and outer layer of $36 \mu \mathrm{m}$; the back coating thickness was $17 \mu \mathrm{m}$ for the inner layer 
and $12 \mu \mathrm{m}$ for the outer layer. The subsurface image analysis of the PU aluminum alloy template, Figure 5a,b, indicated the following: a front-coating film inner layer of $21 \mu \mathrm{m}$ and outer layer of $32 \mu \mathrm{m}$, and a back coating film inner layer of $15 \mu \mathrm{m}$ and outer layer $12 \mu \mathrm{m}$.

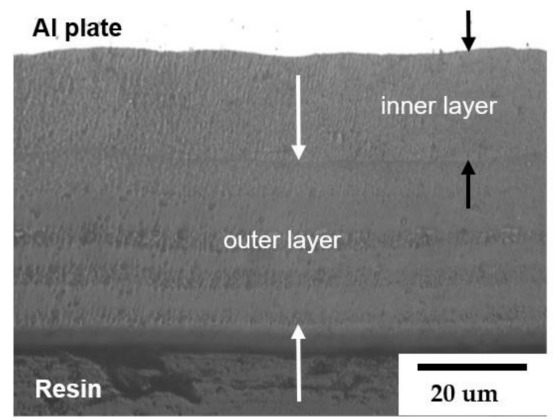

(a)

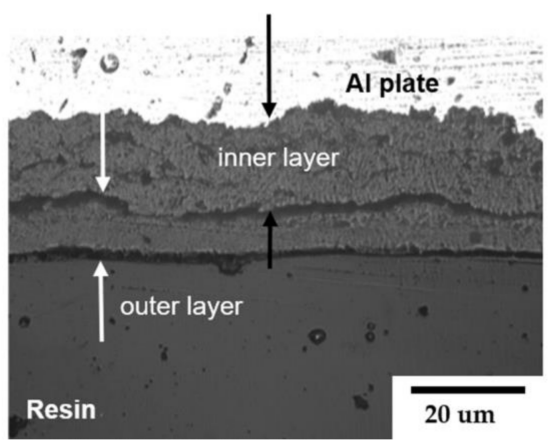

(b)

Figure 4. 5089 aluminum template coating PVDF subsurface structure: (a) front side (b) back side.

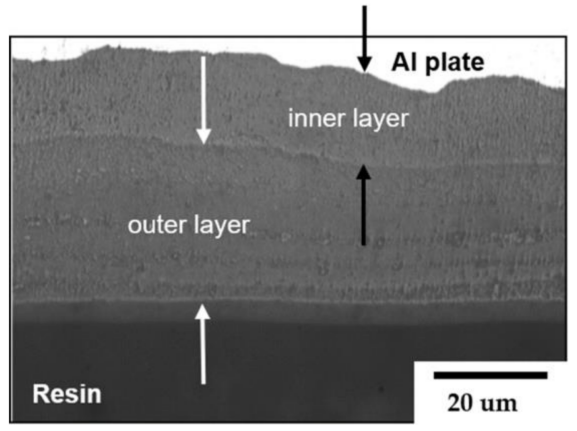

(a)

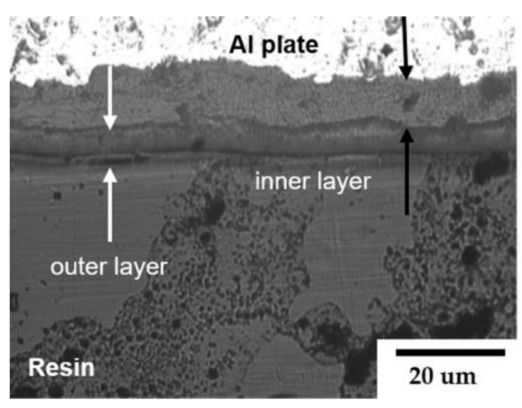

(b)

Figure 5. 5089 Aluminum template coating PU subsurface structure: (a) front side (b) back side.

The tensile test was performed in accordance with ASTM-B209. The test results (Table 2) indicated that for the lightweight 5089 aluminum template, UTS $=340 \mathrm{MPa}$, $\mathrm{YS}=224 \mathrm{MPa}, \mathrm{UE}=12.8 \%$, and $\mathrm{TE}=18.0 \%$. Compared with 5000 series Aluminum alloy, the 5089 template used in this study was confirmed to have higher strength because it contained $\mathrm{Cu}$ and $\mathrm{Cr}$. The mechanical properties recorded by the tensile machine after the surface of the 5089 Aluminum template was coated with PVDF or PU are summarized in Table 2. The tensile mechanical properties of the PVDF-coated 5089 Aluminum template were superior to those of the PU-coated test piece. The differences in tensile properties are attributable to the higher hardness and ultimate tensile strength (UTS) of the PVDF coating than those of the PU coating (Shore A of hardness, PVDF =68, PU = 52; UTS, $\mathrm{PVDF}=65 \mathrm{MPa}$, and $\mathrm{PU}=50 \mathrm{MPa}$ ). Therefore, the tensile strength of the PVDF coating was higher than that of the PU coating.

Table 2. Tensile stress, elongation, and yield stress for 5089:TE, total elongation; UE, uniform elongation; YS, yield strength.

\begin{tabular}{ccccc}
\hline Probes & YS (MPa) & UTS(MPa) & UE (\%) & TE (\%) \\
\hline 5089 & 224 & 340 & 12.8 & 18.0 \\
\hline PVDF & 229 & 349 & 12.3 & 18.2 \\
\hline PU & 204 & 333 & 12.1 & 19.5 \\
\hline
\end{tabular}

The salt spray test was conducted in accordance with ASTM B117/ASTM G23 (the experimental hours were $625 \mathrm{~h}$ and $1250 \mathrm{~h}$ ). As Tables 3 and 4 suggest, the PVDF test piece 
exhibited higher corrosion resistance and had YS > $200 \mathrm{MPa}$. After the salt spray test, the surface of the test piece was normal without discoloration, corrosion, or blistering, and salt residue was present. Furthermore, the PVDF piece retained its strength and elongation after the 1250-h salt spray test. By contrast, the PU piece exhibited considerable embrittlement after the salt spray test. Thus, the PVDF coating performed more highly than did the PU coating.

Table 3. PVDF- coated 5089 Aluminum template. Tensile curve strength, elongation, and drop strength after salt spray.

\begin{tabular}{ccccc}
\hline hr (s) & YS (MPa) & UTS (MPa) & UE (\%) & TE (\%) \\
\hline 0 & 229 & 349 & 12.3 & 18.2 \\
\hline 625 & 221 & 341 & 11.1 & 17.3 \\
\hline 1250 & 220 & 333 & 10.8 & 15.3 \\
\hline
\end{tabular}

Table 4. PU-coated 5089 Aluminum template, tensile curve strength, elongation, and drop strength after salt spray.

\begin{tabular}{ccccc}
\hline hr(s) & YS (MPa) & UTS (MPa) & UE (\%) & TE (\%) \\
\hline 0 & 204 & 333 & 12.1 & 19.5 \\
\hline 625 & 198 & 325 & 11.4 & 19.2 \\
\hline 1250 & 185 & 302 & 9.8 & 18.5 \\
\hline
\end{tabular}

The erosion and abrasion test (Figure 6) employed a dry particle erosion and abrasion test method. The erosion particle size was approximately $295 \mu \mathrm{m}$, the erosion pressure was $3 \mathrm{~kg} / \mathrm{mm}^{2}$, and the amount of erosion sand was $500 \mathrm{~g}$. The experimental results indicated that the wear resistance of PVDF was higher than that of PU at all erosion angles. The two curves in Figure 6 exhibit a highest abrasion rate at $30^{\circ}$ and lowest abrasion rate at $90^{\circ}$, indicating that the abrasion at these angles was the result of ductile-dominated wear failure behaviors.

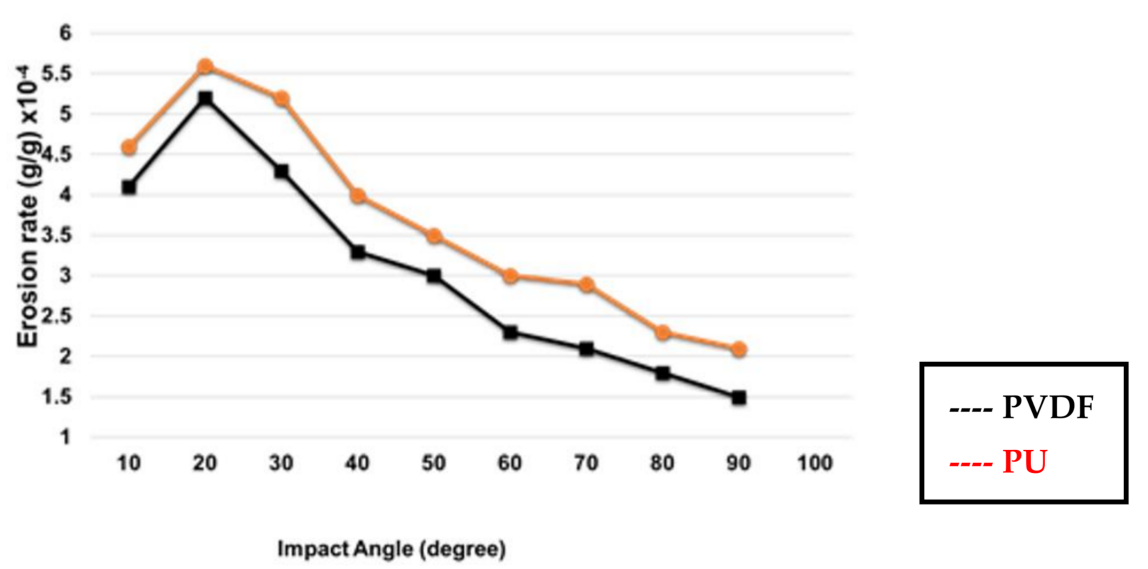

Figure 6. Particle erosion angle and wear resistance.

The weather resistance test as performed in accordance with ASTM G53, and the exposure time was $1500 \mathrm{~h}$. The test result was normal, and the grade was less than NO.4 (ASTM D4214; ASTM D659), ASTM D523 600-11\%; ASTM D2244 color change 1 NBS. The hardness test was performed in accordance with the ASTM D3363 specifications, and the test results signified that the $3 \mathrm{H}$ hardness was normal (Table 5). 
Table 5. Hardness test.

\begin{tabular}{ccc}
\hline Hardness & PVDF & PU \\
\hline HK 0.01 (MPa) & 86.3 & 81.9 \\
\hline Conversion to HRF $(\mathrm{MPa})$ & 71.7 & 68.4 \\
\hline
\end{tabular}

The humidity resistance test was conducted in accordance with ASTM D2247; the exposure temperature was $38 \pm 1{ }^{\circ} \mathrm{C}$, exposure humidity was $100 \%$, and exposure time was $1500 \mathrm{~h}$. Both the PVDF and PU had normal humidity resistance (ASTM D523 600-9\%; ASTM D2244-color change amount of 1 NBS). In addition, the results of the bending, adhesion resistance, alkali resistance, and acid resistance tests were all normal. The experimental results are provided in Table 6 .

Table 6. Experimental test pieces method specifications and result.

\begin{tabular}{|c|c|c|}
\hline Test piece & Test name and Method & Result \\
\hline PVDF & \multirow{2}{*}{$\begin{array}{c}\text { 1. Bending } \\
\text { 2. Specifications: ASTM-D1737 }\end{array}$} & \multirow{2}{*}{$\begin{array}{l}\text { (1) Tests were all normal } \\
\text { (2) No cracks on the surface. }\end{array}$} \\
\hline PU & & \\
\hline PVDF & \multirow{2}{*}{$\begin{array}{l}\text { 1. Adhesion Resistance } \\
\text { 2. Specifications: ASTM-D3359 }\end{array}$} & \multirow{2}{*}{$\begin{array}{l}\text { (1) Tests were all normal } \\
\text { (2) } 1 \mathrm{~mm} \text { square } 100 \% \text { adhesion. }\end{array}$} \\
\hline PU & & \\
\hline PVDF & \multirow{2}{*}{$\begin{array}{l}\text { 1. Alkali resistance } \\
\text { 2. Specifications: ASTM-D1308 } \\
\text { 3. Times:500 hrs }\end{array}$} & \multirow{2}{*}{$\begin{array}{l}\text { (1) Tests were all normal } \\
\text { (2) No discoloration, corrosion and } \\
\text { blistering. }\end{array}$} \\
\hline PU & & \\
\hline PVDF & \multirow{2}{*}{$\begin{array}{l}\text { 1. Acid Resistance } \\
\text { 2. Specifications:ASTM-D1308 } \\
\text { 3. Times:500 hrs }\end{array}$} & \multirow{2}{*}{$\begin{array}{l}\text { (1) Tests were all normal } \\
\text { (2) No discoloration, corrosion and } \\
\text { blistering. }\end{array}$} \\
\hline PU & & \\
\hline
\end{tabular}

The results of repeated cement adhesion experiments for the PVDF aluminum template indicated that this template was superior to the PU aluminum template. Figure 7 presents a photograph of the first cement coating test. The results of the test revealed that the PVDF had superior anti-adhesion property. After the cement adhesion test had been performed five times, the PVDF 5089 Aluminum template was found to continue to exhibit superior antiadhesive cement property, and no significant difference in coating color was observed (Figure 8).

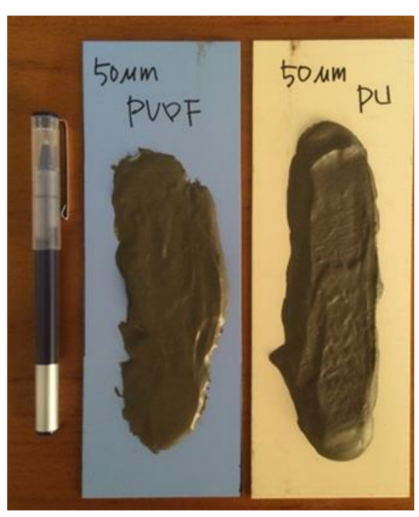

(a)

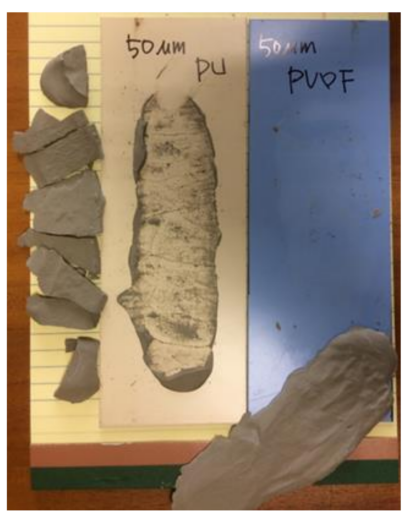

(b)

Figure 7. First PVDF and PU aluminum template cement adhesion experiment: (a) The template was coated with cement; (b) the dry cured cement peeled off, with the coating adhering to it. 


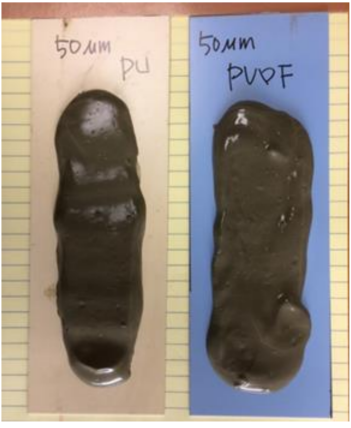

(a)

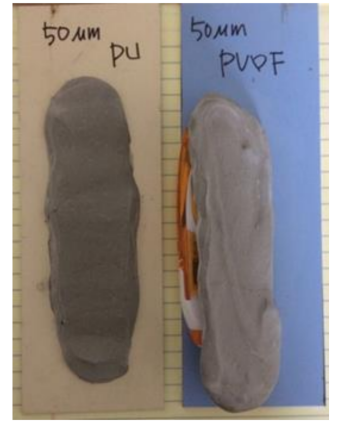

(b)

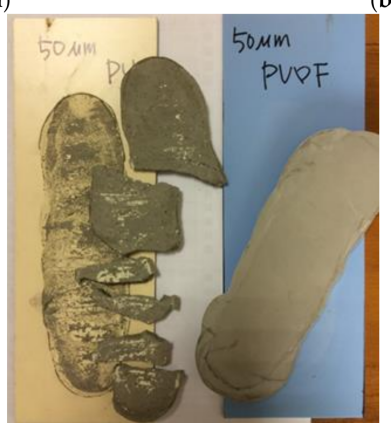

(c)

Figure 8. Fifth PVDF and PU aluminum template cement adhesion experiment: (a) The template was coated with cement; (b) the cement was dry cured; and (c) the dry cured cement peeled off, with the coating adhering to it.

Figure 9 illustrates the result of the cement adhesion test after it was performed ten times. The results confirmed that the PVDF 5089 Aluminum template had favorable antiadhesion property. However, considerable amount of cement was found to adhere to the PU 5089 coating, which is not conducive to subsequent aluminum template applications.

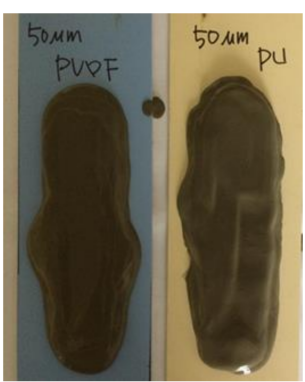

(a)

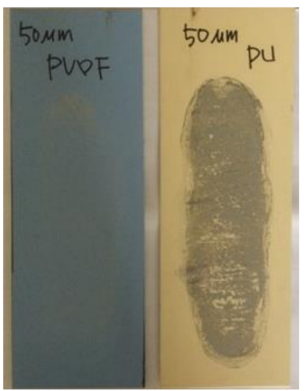

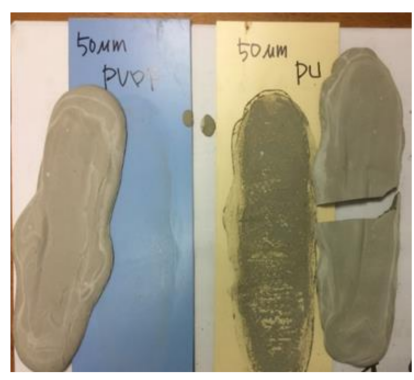

(b)

(c)

Figure 9. Tenth PVDF and PU Aluminum template cement adhesion experiment: (a) The template was coated with cement for construction; (b) the cement was dry cured; and (c) the dry cured cement peeled off, with the coating adhering to it. 
5089 Aluminum template has excellent corrosion resistance and mechanical properties. In addition, PVDF coating can adhere to 5089 Aluminum template and has good density. So it can inhibit cement adhesion and increase the quality and efficiency of buildings.

\section{Conclusions}

First, the mechanical properties of the lightweight 5089 Aluminum template were superior to those of commercial 5000 series alloys. The surface coated with PVDF or PU exhibited favorable coating adhesion. The coating structure was dense, and no pores formed.

Second, comparisons determined that the material properties of the PVDF-coated 5089 Aluminum template were superior to those of the PU-coated template, especially in terms of strength, hardness, and particle erosion resistance. The main reason is PVDF contains fluorine and is denser. The erosion and abrasion behavior of the two specimens was dominated by the ductile failure mechanism. Maximum erosion occurred when the erosion angle is $30^{\circ}$ oblique, and the lowest erosion rate occurred at $90^{\circ}$.

Third, the repeated cement adhesion test confirmed the following: the $5089 \mathrm{Alu}-$ minum template coated with PVDF had superior ability to prevent cement adhesion and underwent less of a change in color due to cement corrosion. Therefore, the template is suitable for the construction industry, for shipbuilding, and as a reference for wind power engineering applications.

Author Contributions: Conceptualization, F.S.H.; methodology, F.S.H.; software, F.S.H.; validation, Hung, F.-S; formal analysis, F.S.H.; investigation, F.S.H.; resources, F.S.H.; data curation, F.S.H.; writing - original draft preparation, F.S.H.; writing—review and editing, F.S.H.; visualization, F.S.H.; supervision, F.S.H.; project administration, F.S.H.; funding acquisition, F.S.H. The author has read and agreed to the published version of the manuscript.

Funding: This research was supported by the Ministry of Science and Technology of Taiwan, ROC.

Institutional Review Board Statement: Not applicable.

Informed Consent Statement: Not applicable.

Data Availability Statement: No new data were created or analyzed in this study. Data sharing is not applicable to this article.

Acknowledgments: The author is grateful to the Department of Leisure, Recreation and Tourism Management, Southern Taiwan University of Science and Technology for the support of this research.

Conflicts of Interest: The author declares no conflict of interest.

\section{References}

1. Guillon, O.; Roizard, X.; Belliard, P. Experimental methodology to study tribological aspects of deep drawing application to aluminum alloy sheets and tool coatings. Tribol. Int. 2001, 34, 757-766. [CrossRef]

2. Yang, C.-W.; Hung, F.-Y.; Lui, T.-S.; Chen, L.-H.; Juo, J.-Y. Weibull Statistics for Evaluating Failure Behaviors and Joining Reliability of Friction Stir Spot Welded 5052 Aluminum Alloy. Mater. Trans. 2009, 50, 145-151. [CrossRef]

3. Ozturk, F.; Esener, E.; Toros, S.; Picu, C.R. Effects of aging parameters on formability of 6061-O alloy. Mater. Des. 2010, 31, 4847-4852. [CrossRef]

4. Barnwal, V.K.; Raghavan, R.; Tewari, A.; Narasimhan, K.; Mishra, S.K. Effect of microstructure and texture on forming behavior of AA-6061 aluminum alloy sheet. Mater. Sci. Eng. A. 2017, 679, 56-65. [CrossRef]

5. Ding, L.; Jia, Z.; Nie, J.-F.; Weng, Y.; Cao, L.; Chen, H.; Wu, X.; Liu, Q. The structural and compositional evolution of precipitates in Al-Mg-Si-Cu alloy. Acta Mater. 2018, 145, 437-450. [CrossRef]

6. Hung, F.-S. Material Application of a Transformer Box: A Study on the Electromagnetic Shielding Characteristics of Al-Ta Coating Film with Plasma-Spray Process. Coatings 2019, 9, 495. [CrossRef]

7. Darmawan, A.S.; Siswanto, W.A.; Purboputro, P.I.; Anggono, A.D.; Masyrukan; Hamid, A. Effect of Increasing Salinity to Corrosion Resistance of 5052 Aluminum Alloy in Artificial Seawater. Mater. Sci. Forum 2019, 961, 107-111. [CrossRef]

8. Rasouli, S.A.; Behnagh, R.; Dadvand, A.; Saleki-Haselghoubi, N. Improvement in corrosion resistance of 5083 aluminum alloy via friction stir processing. Proc. Inst. Mech. Eng. Part. L J. Mater. Des. Appl. 2014, 230, 142-150. [CrossRef]

9. Shen, X.; Liu, H.; Cheng, X.-B.; Yan, C.; Huang, J.-Q. Beyond lithium ion batteries: Higher energy density battery systems based on lithium metal anodes. Energy Storage Mater. 2018, 12, 161-175. [CrossRef] 
10. Vanesa, C.B.; Joshua, K. Energy access is needed to maintain health during pandemics. Nat. Energy 2020, 5, 419-421.

11. Weber, R.; Genovese, M.; Louli, A.J.; Hames, S.; Martin, C.; Hill, I.G.; Dahn, J.R. Long cycle life and dendrite-free lithium morphology in anode-free lithium pouch cells enabled by a dual-salt liquid electrolyte. Nat. Energy 2019, 4, 683-689. [CrossRef]

12. Jang, J.Y.; Do, J.Y. Synthesis and evaluation of thermoplastic polyurethanes as thermo-optic waveguide materials. Polym. J. 2014, 46, 349-354. [CrossRef]

13. Wang, C.-H.; Hou, G.-G.; Du, Z.-Z.; Cong, W.; Sun, J.-F.; Xu, Y.-Y.; Liu, W.-S. Synthesis, characterization and antibacterial properties of polyurethane material functionalized with quaternary ammonium salt. Polym. J. 2015, 48, 259-265. [CrossRef]

14. Chen, Q.; Mangadlao, J.D.; Wallat, J.; De Leon, A.; Pokorski, J.K.; Advincula, R.C. 3D Printing Biocompatible Polyurethane/Poly(lactic acid)/Graphene Oxide Nanocomposites: Anisotropic Properties. ACS Appl. Mater. Interfaces 2017, 9, 4015-4023. [CrossRef] [PubMed]

15. Zhang, L.; Kong, Q.; Kong, F.; Liu, T.; Qian, H. Synthesis and surface properties of novel fluorinated polyurethane base on F-containing chain extender. Polym. Adv. Technol. 2019, 31, 616-629. [CrossRef]

16. Zhao, B.; Jia, R.; Zhang, Y.; Liu, D.; Zheng, X. Design and synthesis of antibacterial waterborne fluorinated polyurethane. J. Appl. Polym. Sci. 2019, 136, 46923. [CrossRef]

17. Oprea, S. Effect of Composition and Hard-segment Content on Thermo-mechanical Properties of Cross-linked Polyurethane Copolymers. High. Perform. Polym. 2008, 21, 353-370. [CrossRef]

18. Lee, S.R.; Kim, M.R.; Jo, E.H.; Yoon, K.-B. Synthesis of very low birefringence polymers using fluorinated macromers for polymeric waveguides. High. Perform. Polym. 2015, 28, 131-139. [CrossRef]

19. Wu, C.; Chiu, S.; Lee, H.; Suen, M. Synthesis and properties of biodegradable polycaprolactone/polyurethanes using fluoro chain extenders. Polym. Adv. Technol. 2015, 27, 665-676. [CrossRef]

20. Kerr, S.; Naumkin, F.Y. Noncovalently bound complexes of polar molecules: Dipole-inside-of-dipole vs. dipole-dipole systems. New J. Chem. 2017, 41, 13576-13584. [CrossRef]

21. Xu, W.; Zhao, W.; Hao, L.; Wang, S.; Pei, M.; Wang, X. Synthesis of novel cationic fluoroalkyl-terminated hyperbranched polyurethane latex and morphology, physical properties of its latex film. Prog. Org. Coatings 2018, 121, 209-217. [CrossRef]

22. Zhao, J.; Zhu, W.; Yan, W.; Wang, X.; Liu, L.; Yu, J.; Ding, B. Tailoring waterproof and breathable properties of environmentally friendly electrospun fibrous membranes by optimizing porous structure and surface wettability. Compos. Commun. 2019, 15, 40-45. [CrossRef]

23. Hung, F.-S. Design of lightweight aluminum alloy building materials for corrosion and wear resistance. Emerg. Mater. Res. 2020, 9, 750-757. [CrossRef]

24. Hung, F.; Chen, L.; Lui, T. A study on erosion of upper bainitic ADI and PDI. Wear 2006, 260, 1003-1012. [CrossRef] 